\title{
Education for Jobs - Preparation for the Labor Market
}

\author{
Jana Petnuchová
}

\begin{abstract}
The article describes importance of vocational education and training (VET) which can play a central role in preparing young people for work, developing the skills of adults and responding to the labor market needs of the economy. The aim of this article is to highlight the definitions and understandings of vocational education and training (VET). Countries are now giving the long-neglected topic of vocational education and training dramatically increased profiles, reflecting recognition of its economic function. Many countries are recognizing that good initial vocational education and training has a major contribution to make to economic competitiveness.
\end{abstract}

Keywords: vocational education, vocational teacher, educational and training programs, labor market needs.

\section{Situation in Europe}

Many of unskilled jobs which existed in OECD countries a generation ago are fast disappearing, either because they have been replaced by technology or because these countries cannot compete with less developed countries on labor costs. Instead, OECD countries need to compete on the quality of goods and service they provide. That requires a well-skilled labor force with a range of mid-level trade, technical and professional skills alongside those high-level skills associated with university education more often than not, those skills are delivered through vocational programs (Field and Kuczera, 2010).

Vocational education and training (VET) can play a central role in preparing young people for work, developing skills of adults and responding to the labormarket needs of the economy. It means building a foundation of basic and

\footnotetext{
* Jana Petnuchová, Constantine The Philosopher University in Nitra, Nitra, Slovakia; jana.petnuchova@ukf.sk
} 
transferable skills into vocational qualifications to reflect a world career flux and development rather than one job for life. It means renewal of the career guidance profession to deliver active guidance for all young leaders, well-informed by knowledge of the labor market and vocational as well as academic pathways. It means ensuring that teachers and trainers in VET programs have up-to-date industry experience (OECD, 2009).

Initial VET is designed to fill the gap providing the needed skills, and research has shown that it can yield good economic returns from the public investment involved. Countries with strong initial VET programs like Germany have been relatively successful in tackling youth employment (OECD, 2010).

Historically, many vocational programs were conceived as a stepping stone to a single target occupation. But increasing educational opportunities have challenged this. More and more young people including students in vocational programs now expect to enter tertiary and other postsecondary education. For example, one quarter of Dutch upper secondary vocational students continue into tertiary VET and around three-quarters of Korean upper secondary vocational students do so (OECD, 2010).

Among general academic skills numeracy and literacy are increasing importance in the labor market and weaknesses in these fields are very common those in vocational programs. VET programs need to give sufficient weight to these skills and students should be systematically assessed at the point of entry to vocational programs as to ensure a basic minimum of skills and identify those in need targeted support (Eurostat, 2002).

In a review of adult education and vocational training in Europe, Tuijnman draws on a range of studies carried out throughout Europe to identify general trends in European training, and while he states that countries are moving in different directions, the one common trend he identifies is the marked quantitative growth in vocational education and training (VET). Thus, the concerns of governments and employers alike about vocational training have been reflected by an increased investment into this area. A number of European studies have argued that economic success depends on having a competitive „high-tech“ industry and that previous under investment into VET have undermined European efforts to respond to changing economic conditions, thus most European countries are now placing a ,heavy emphasis on policies to improve job training“" (Tuijnman,1992).

Governments in countries such as France or Germany have taken a strong role in creating training structures and providing legislative back-up. France, for example has provided individual rights to training leave, and has a remissible training levy on all employers. In Germany, there is a compulsory employer membership of training bodies (Keep, 1993).

In 1991 the National Institute of Adult and Continuing Education stated that 7 percent of employees had had no recent training or education opportunities at work (Forrester et al., 1995) 
- In 1991 an Employment Department report "Skills need in Britain" found that 29 percent of British companies have no training plan and 34 per cent have no training budget (Forrester,1995)

- In Germany about 67 per cent of all workers possess vocational qualifications, in the UK the figure is about 36 per cent (Keep,1993)

- In Slovakia for example only 30-35 percent employed got over vocational training for new jobs (Ministry of Education, Science, Research and Sport of the Slovak Republic).

\section{Teachers and their place in vocational education and training (VET)}

As in general education, the key component in a good vocational program is a good teacher. The current workforce ages, many countries are facing a shortage of teachers and trainers in VET institutions. Part-time work should also be promoted, with trainers in VET institutions working part-time industry, thus sustaining their industrial know-how. But, in industry a different problem emerges. Trainers and supervisors of apprentices and trainees in companies often have no specific pedagogical preparation or other preparation. Although research evidence shows that such pedagogical preparation has positive outcomes (OECD, 2010).

The growth of open learning in the context of vocational education has highlighted the tension between open Access and open pedagogy (Robinson, 1989).

Appropriate pedagogical and other preparation for supervisors of interns, trainers and apprentices in workplaces should be provided, adapting the level of preparation to the nature of the workplace learning being provided (OECD, 2009).

On 22 September 2005 in Copenhagen (OEDC, 2005) the chief civil servants of education ministries from across the OECD opened a two-day discussion. Their agenda was wide-ranging. They have been asked to identify their most important policy priority in education in the coming years. The answer they gave surprised many, for it was neither schools nor universities, but in fact, vocational training and education (VET).

Three factors stand out as reasons for growing interest of policy makers in VET: economics, strains in the system and previous neglect.

Economics - since OECD countries cannot compete with less developed countries on labor costs, they need to compete in terms of the quality of goods and services they provide. That means highly skilled labor force, technical and professional skills alongside those high-level skills associated with university education (Field and Kuczera et al., 2010). 
Strains - there are strains in VET system. One of them is the lack of workplace training places, and another is the lack of trainers. In some countries the rapid expansion of tertiary education has undermined school-based VET. For example in the United States a new terminology of „,career and technical education“ has replaced „vocational education and training " to reflect an orientation towards a career rather than a single occupation (OECD, 2010).

VET has been neglected. Challenging issues like how to go about teaching practical skills, or the rapid expansion of tertiary programs, have received limited attention. The perceived low status of VET has therefore also been a barrier to engagement in the sector and how it has been viewed analytically. One object of this review is to remedy this past neglect (Lugvig and Pfeiffer, 2005).

Vocational education and training (VET) includes education and training programs designed for, and typically to a particular job or type of job. It normally involves practical training as well as the learning or relevant theory. It is distinct from (academic) education-for example in mathematics, which is relevant to a very wide range of jobs. Education and training for some high level professions such as medicine and law meets the definition even though they are not normally described as VET. Initial VET includes programs mainly designed for and used by young people under 30 at the beginning of their career and commonly before entering the labor market. It includes many upper secondary and tertiary programs. Continuing VET is all other sorts of VET, including enterprise training of employees and training provided specially for those who have lost their job (OECD, 2010).

\section{National systems of vocational education and training.}

National systems of VET are very diverse-and indeed in some countries it makes little sense to refer to it as a single „system“. Many countries have extensive vocational programs at upper secondary level while others, particularly English-speaking countries, tend to postpone such programs to postsecondary level. Among countries for which data are available in 2009 survey (OECD, 2011), in 13 OECD countries, the majority of upper secondary students pursue pre-vocational or vocational education.

In most OECD countries with dual - system apprenticeship programs (Austria, Germany, Luxembourg, the Netherlands, and Switzerland) and in Argentina, Belgium, China, the Czech Republic, Finland, Italy, Norway, the Slovak Republic, Slovenia, and Sweden at least 50 percent of upper secondary students are enrolled in pre - vocational or vocational training programs ( in Brazil, Canada, Chile, Estonia, Greece, Hungary, Iceland, India, Indonesia, Ireland, Israel, Korea, Japan, Mexico, New Zealand, Portugal and the United Kingdom at 
least 60 per cent of upper secondary students are enrolled in general programs even though pre-vocational) vocational programs are offered (OECD, 2011). Vocational programs among OECD countries offer a different combination of vocational programs and students can enroll in, but many OECD countries delay vocational training until after graduation from upper secondary education. While vocational programs are offered as advanced upper secondary education in Austria, Hungary, Spain, similar programs are offered as post-secondary education in Canada (OECD, 2011).

Young people with an insufficient level of education are often at a greater risk of unemployment and other exclusions than their more educated peers. In many OECD countries the transition from education to the market labor has become longer and more complex - providing an opportunity, or creating the necessity to combine learning and work to develop skills adapted to the labor market.

The return to or continuation of studies is an option for adults to increase or diversify their skills and make them more adaptable to the changing demands of the labor market. In times of increasing unemployment, and of a potential structural evolution in the demands for skills, some countries, such as Chile, have established specific policies to encourage adults to follow tertiary - type B studies. The general rises in unemployment rates in OECD countries between 2008 and 2009 did not lead to a significant increase in enrolment among adults in this period. There is also no direct correlation between growth in enrolment rates between 2008 and 2009 and the increases in unemployment rates that were seen between 2007 and 2008 in some OECD countries because other factors, such as labor force mobility within the European Union and unemployment benefits, may influence adults' decision to return to education (OECD, 2011).

Quintini and Manfredi (2009) discuss different transition patterns from school to work across OECD countries. They note that in countries with regulated labor markets and strong apprenticeship systems such as Germany, about 80 per cent of school leavers succeed in integrating into the labor market. Such countries contrast with countries with regulated labor markets but without strong workbased training integrated into the formal school system, such as Italy and Spain where more than a third of young people end up in unemployment or inactivity. The German transition is impressive, especially the transition rate of graduates from vocational high school who have the same employment rate as tertiary graduates at the beginning of their career (OECD, 2010).

\section{Crossroads}

Young people in education make choices - to study another foreign language, take advanced math, or opt for a vocational catering course and etc. These 
choices are hard, and can have lasting consequences. They are also constrained: some options are not available or not funded by government. Students and employers preferences may overlap but there also will be some differences. Employers expect VET to provide them with the best employees equipped with skills they need. Policy makers for VET (as for other parts of education) have to decide how far to give students the programs they prefer and how far to provide the programs corresponding to employer needs. In addition, countries can only provide vocational programs where they have the teachers, the trainers, and the facilities necessary to the task (Field, Kuczera et al., 2010).

In VET as in other many public policy areas, some countries are seeking to use the market as a device for increasing efficiency. One potential advantage of competition is that it may force the system to respond to student preferences in respect of the mix of provision, VET institutions offering an attractive programs will lose both students and funding (Bradley et al., 2001).

Given that the benefits of VET are realized both by students and employers, an effective VET system needs to reflect both employer demand and student preference. The relative weight given to these factors varies across countries. But optimal balance depends on factors including:

- Who pays? If students pay most or all of the costs of VET courses-for example at postsecondary level-then the mix should be equivalently dominated by student preference

- Student age - younger, school-age students may less able to make longer -term career decisions, so student preferences for certain vocational programs should be balanced by attention to labor market outcomes, particularly where provision is free of charge to the student

- Breadth and orientation of program - programs with a large element of general skills, often designed to prepare students for the next level education, as well as direct labor market entry, need to be constrained so tightly by employer demands.

- Predictability - in some sectors, like in education and health care, labor force requirements may be more predictable then in some others (Field and Kuczera, 2010).

The rationale of vocational programs is that they will provide the skills needed in future jobs. But the shape of future labor market is inevitably misty. Many OECD countries (Australia, Canada, Ireland and Finland) forecast trends in employment mainly by occupational categories often a time horizon of five to ten years (Neugart and Schomann, 2002).The European Union has also created medium-term skills forecasts in the EU as a whole and in each member country (CEDEFOP, 2008). The 2008 Spring European Council called for a comprehensive assessment of skills requirements in Europe up to 2020 (fig.1). This request was also taken up in the June 2008 Council conclusions „Anticipating and matching labor market needs, with special emphasis to youth - a job and skills initiative". 


\begin{tabular}{|c|c|c|c|}
\hline Levels & 2001 & 2015 & 2020 \\
\hline Armed forces & 1,197 & 1,165 & 1,130 \\
\hline Professionals & 25,482 & 31,111 & 33,275 \\
\hline $\begin{array}{l}\text { Technicians and } \\
\text { associated } \\
\text { professionals }\end{array}$ & 31,733 & 38,691 & 41,502 \\
\hline Clerks & 25,088 & 22,044 & 21,436 \\
\hline $\begin{array}{l}\text { Service workers, } \\
\text { shop and markets } \\
\text { workers }\end{array}$ & 28,717 & 32,017 & 32,702 \\
\hline $\begin{array}{lr}\text { Skilled } & \text { fishery } \\
\text { workers } & \text { and } \\
\text { agricultural } & \\
\text { workers } & \\
\end{array}$ & 8,960 & 6,082 & 5,549 \\
\hline $\begin{array}{l}\text { Plant and machine } \\
\text { operators and } \\
\text { assemblers }\end{array}$ & 17,304 & 17,85 & 18,260 \\
\hline $\begin{array}{l}\text { Elementary } \\
\text { occupations }\end{array}$ & 21,137 & 26,480 & 28,064 \\
\hline
\end{tabular}

Fig.1 Employment by occupation EU25 (CEDEFOP, 2008).

\section{Conclusion}

Various studies highlight the importance of general content in the curriculum. In modern economies an increasing number of jobs, including blue-collar jobs, require sound generic skills. A study from the United States (Levy and Murnane, 2004) suggests that technological change has made problem solving and complex communication skills much more important in the labor market. The development of these skills is underpinned by good literacy and numeracy skills (Levy and Murnane, 2004).

Labor markets change rapidly and often unpredictably. As virtually all workers will need to acquire new skills during their career, literacy and numeracy are particularly valuable in the long run (Kézdi, 2006). Strong literacy and numeracy skills are associated with better performance on the labor market.

For some students in VET programs, very weak basic skills are a serious difficulty. Basic skills problems are widespread, damaging, often unrecognized, but remediable. It follows that there is a very strong argument for systematically assessing the literacy and numeracy skills of students at the point of entry to vocational programs so as to identify people in need of support. In Belgium, for 
example, jobseekers complete a quick-scan test and, if necessary, are directed to adult basic education centers (Basic Skills Agency, 1997).

In many countries, surveys show that employers strongly value soft skills, such as the ability to work in a team, communication skills and work discipline. In Austria for example a survey found that the lack of soft skills, such as reliability and adequate manners, was a common reason for rejecting apprenticeship applicants (Schneeberger, 2007).

Other skills, such as entrepreneurship, are highly relevant to many occupations to which VET leads, but have been often neglected in traditional vocational programs. Some countries have recognized the importance of entrepreneurial skills and have created programs in this area. In Belgium the Flemish agency for Entrepreneurial Training (Syntra Vlaanderen) aims to stimulate entrepreneurship. It offers a range of training programs, including courses in business management, entrepreneurial training as part of apprenticeships, and specific entrepreneurial training at ISCED 4 level (Field and Kuczera, 2010).

\section{References:}

Basic Skills Agency: Staying the Course. The relationship between basic skills support and drop out, retention and achievement in further education colleges. London: Basic skills agency, 1997.

BRADLEY, S. et al.: The Effect of Competition on the Efficiency of Secondary Schools in England. In: European Journal of Operational Research, vol.135, n.3.

CEDEFOP: Future Skills needs in Europe-Medium term-forecast. Luxembourg: Office for Official Publications of the European Communities, 2008.

EUROSTAT: European Social Statistics. In: Continuing Vocational Training Survey (CVTS2), Luxemburg, 2002.

FIELD, S. - KUCZERA, M. et al.: Learning for Jobs. Synthetic report of the OECD. In: Reviews of Vocational Education and Training. OECD, 2010.

FORRESTER, K. et al.: Workplace learning, Avebury. Aldershot, 1995.

KEEP, E.: Missing, Presumed Skilled: Training Policy in the UK, In: SIEMENSKI, R. - ZELDIN, D.: Adult learner: Education and Training. London: Open University and Routledge, 1993.

KEZDI, G.: Not Only Transition: The Reasons for Declining Returns to Vocational Education. CERGE-EI, 2006.

LEVY, F. - MURNANE, R. J.: Education and the Changing Job Market. Educational leadership. Princeton, NJ: Princeton University Press, 2004.

LUDVIG, V. - PFEIFFER, F.: Abschreibungsraten allgemeiner und beruflicher Ausbildungsinhalte, ZEW Diskussion Paper, 2005. 
NEUGART, M. - SCHOMANN, K. Employment outlooks? Why Forecast the labor market and for whom? Discussion paper FS I 02-205, Wissenschaftszentrum Berlin fur Sozialforschung, 2002.

OECD: Chair's Summary Meeting of the Education Chief Executives, Copenhagen, 22 to 23 September, 2005. Paris: OECD, 2005. [online]. www.oecd.org/dataoecd/56/34/35555721.pdf

OECD: Education at the Glance. Paris: OECD, 2009.

OECD: Designing Local Skills Strategies. Paris: OECD, 2010.

OECD: Economic Survey of Germany, Paris: OECD, 2010.

OECD: Access to Participation, Education and Progress. OECD, 2011. [online]. http://www.oecd.org/dataoecd/61/34/48631055.pdf

OECD: Access to Participation, Education and Progress. OECD, 2011. [online]. http://www.oecd.org/dataoecd/61/34/48631055.pdf

ROBINSON, K.: Open and Distance Education for Nursers, Longman, Harlow, 1989.

SCHNEEBERGER, A.: Hemmende und Fornderde Faktoren der Lehrlingsufnahme, Ergenisse einer Lehrbetriebsbefragung. IBW-Bildung and Wirthschaft, 2007, n. 41. [online]. www.ibw.at

TUIJMAN, A. C.: The Expansion of Adult Education and Training in Europe. Trends and Issues. In: International Review of education, 38, 1992.

QUINTINI G. - MANFREDI, T.: Going Separate Ways? School-to-Work Transition in the United States and Europe. OECD Social, Employment and Migration Working Paper No.90, Paris: OEDC, 2009. 